Abstracta Iranica

Revue bibliographique pour le domaine irano-aryen

Volume 37-38-39 | 2018

Comptes rendus des publications de 2014-2016

\title{
Jeanne-Nicole Mellon Saint-Laurent. Missionary Stories and the Formation of the Syriac Churches
}

\section{Christelle Jullien}

\section{(2) OpenEdition \\ 12 Journals}

\section{Édition électronique}

URL : http://journals.openedition.org/abstractairanica/44321

DOI : 10.4000/abstractairanica.44321

ISBN : 1961-960X

ISSN : 1961-960X

Éditeur :

CNRS (UMR 7528 Mondes iraniens et indiens), Éditions de l'IFRI

Référence électronique

Christelle Jullien, « Jeanne-Nicole Mellon Saint-Laurent. Missionary Stories and the Formation of the Syriac Churches », Abstracta Iranica [En ligne], Volume 37-38-39| 2018, document 16, mis en ligne le 30 décembre 2018, consulté le 28 septembre 2020. URL : http://journals.openedition.org/ abstractairanica/44321 ; DOI : https://doi.org/10.4000/abstractairanica.44321

Ce document a été généré automatiquement le 28 septembre 2020.

Tous droits réservés 


\title{
Jeanne-Nicole Mellon Saint-Laurent. Missionary Stories and the Formation of the Syriac Churches
}

\author{
Christelle Jullien
}

\section{RÉFÉRENCE}

Jeanne-Nicole Mellon Saint-Laurent. Missionary Stories and the Formation of the Syriac Churches. Oakland: University of California Press, 2015, XI-XII+209 p., 1 carte.

(Transformation of the Classical Heritage 55), ISBN 9780520284968.

1 Fruit d'une thèse de doctorat, ce travail a pour objet l'étude des processus de construction de l'orthodoxie des Églises dans la littérature missiologique syriaque. Il couvre un intervalle-temps allant de l'époque apostolique jusqu'au milieu du VI ${ }^{\mathrm{e}}$ siècle et se subdivise en sept chapitres, chacun étant consacré à l'une des grandes figures missionnaires de la Mésopotamie: trois de la période apostolique (l'apôtre Thomas, Addaï d'Édesse et Mār Mari), et quatre personnalités syro-orthodoxes, des évêques (Jean d'Éphèse, Siméon de Bēth-Aršam, Jacques Baradée et Ahūdemmeh) dont la geste nous est connue grâce à l'Histoire ecclésiastique de Jean d'Éphèse lui-même. Il s'agit essentiellement d'une réflexion sur les représentations des origines de l'Église syrooccidentale à travers l'œuvre de Jean d'Asie. Dans le chapitre introductif sont présentées les principales orientations méthodologiques de l'ouvrage ainsi qu'une réflexion sur le prisme idéalisant des hagiographies à l'étude, dont la finalité est avant tout d'esquisser une image de l'expansion des Églises et d'édifier la communauté chrétienne en proposant des modèles d'imitation, dans le contexte de persécutions sévissant alors dans l'empire byzantin à l'encontre des non-chalcédoniens. En cela, la valorisation de figures bibliques, auxquelles sont identifiés les missionnaires, vient appuyer aussi un positionnement christologique. Ce qui explique aussi l'aspect fortement identitaire de ces récits. L'A. insiste sur l'intérêt de cette littérature pour retrouver en filigrane, au-delà du genre même et de ses interprétations, la réalité 
culturelle et religieuse d'une époque, celle des écrivains syriaques et de leur communauté. Ces récits missionnaires se sont par ailleurs construits dans le cadre de polémiques, et les revendications apostoliques, comme les présentations des succès dans l'évangélisation, servent d'abord à justifier et à légitimer le choix christologique d'une communauté - et finalement son existence même. Sont regroupés à la fin l'ensemble des notes (p. 139-180), une bibliographie (p.183-199, incluant une présentation des sources) et un index général (p. 201-209). Carte succincte (p. XIII).

\section{AUTEURS}

\section{CHRISTELLE JULLIEN}

CNRS, Mondes iranien et indien, Paris 